\section{El lugar de las fuentes orales \\ en los archivos: una cuestión en debate \\ Dora Schwarzstein}

Dora Schwarzstein es Profesora de la Facultad

de Ciencias Sociales de la Universidad de Buenos Aires

y Directora del Programa de Historia Oral de la Facultad

de Filosofía y Letras de la misma Universidad.

Dirección: Programa de Historia Oral, Facultad de Filosofía

y Letras, UBA, Puán 480, (1406) Ciudad de Buenos Aires.

E-mail: schwarzs@retina.ar

\section{Resumen}

El interés generalizado en la recuperación del pasado ha extendido la historia oral transformándola en una herramienta que trasciende la investigación histórica para convertirse en una práctica más general de creación de patrimonio histórico. La eclosión de la historia oral es tal que cuestiona una posible definición única de su práctica. La producción de testimonios orales con distintos objetivos y en diferentes contextos plantea la discusión acerca de la naturaleza de las fuentes producidas. A la vez, la multiplicación de la recolección de testimonios orales en ámbitos muy diversos implica serios problemas de conservación y de acceso. El objetivo de este trabajo es analizar los desafíos que se presentan hoy, en consecuencia, para los archivistas e historiadores.
Versión corregida y modificada de la ponencia presentada en la XXXVème Conference Internationale de la Table Ronde des Archives. Archives et societé: que conserver? La collecte et la sélection. Reykjavik, Islandia, 2001. La autora agradece especialmente a Rob Perks por su ayuda para poder consultar gran parte de los materiales utilizados en la escritura de este artículo.

\section{Summary}

The generalized interest in the recovery of the past has amplified oral history transforming it in a tool that transcends historical research to become a more general practice of creation of historical patrimony. The explosion of oral history is such that it is not possible to offer a unique definition of its practice. The production of oral testimonies with different objectives and in different contexts raises the discussion about the nature of the produced sources. At the same time, the multiplication of the gathering of oral testimonies in very diverse environments raises serious conservation and access problems. The objective of this paper is to analyze the challenges that are presented today, in consequence, for archivists and historians. 